Bangl. J. Vet. Med. (2009). 7(2) : $358-363$

\title{
EFFECT OF SPINACH AGAINST ARSENIC TOXICITY IN RATS
}

\author{
M. Z. Islam*, M. A. Awal, M. Mostofa, A. Ghosh and A. Khair \\ Department of Pharmacology, Faculty of Veterinary Science, Bangladesh Agricultural University, \\ Mymensingh-2202, Bangladesh, ${ }^{*}$ Corresponding author
}

\begin{abstract}
The present study was undertaken with a view to evaluate the efficacy of spinach against arsenic (As) induced toxicity in rats during the period between July to October 2008. Thirty six female Long Evans rats (age about 120days; average body weight at day $0=154.5 \mathrm{~g})$ were randomly divided into three equal groups $(\mathrm{n}=12)$ and marked as $\mathrm{T}_{0}, \mathrm{~T}_{1}$ and $\mathrm{T}_{2}$ groups. Rats of $\mathrm{T}_{0}$ group were given normal feed and water and kept as control. Rats of $T_{1}$ and $T_{2}$ groups were given $5 \mathrm{mg}$ Sodium arsenite $/ \mathrm{kg}$ body weight (BW) and $5 \mathrm{mg}$ Sodium arsenite/ $\mathrm{kg}$ (BW) plus spinach extract $100 \mathrm{mg} / \mathrm{kg}$ body weight respectively daily for 30 days orally. Four rats from each group were sacrificed at 10 days interval in order to quantitatively determine the As content in liver, lungs and kidney by using Hydride Generation Atomic Absorption Spectrophotometer. Serum glutamate oxaloacetate transaminase (SGOT), serum glutamate pyruvate transaminase (SGPT) and serum creatinine were determined by Autoanalyser. No visible clinical sign were observed in any group of experimental rats except loss of body weight in the spinach treated group. Tissue (lung, liver and kidney) concentration of As was significantly $(\mathrm{p}<0.01)$ higher in $\mathrm{T}_{1}$ group rats compared to that of $\mathrm{T}_{0}$ and $\mathrm{T}_{2}$ groups and the highest concentration of As was found in kidney followed by lung and liver in $\mathrm{T}_{1}$ group rats. After 30 days of feeding, spinach significantly $(\mathrm{p}<0.01)$ decreased As from lung, liver and kidney. As intoxication significantly $(\mathrm{p}<0.01)$ increased SGOT values but insignificantly decrease SGPT values and spinach treatment improve these condition. There was no significant effect found in serum creatinine level. It can be concluded that feeding of spinach could reduce body burden of As in rats.
\end{abstract}

Key words: Arsenic, spinach extract, biochemical parameters, rats

\section{INTRODUCTION}

Arsenic creates a serious public health issue in different countries by contaminating the ground water (Rahman, 2006). At present, about half of the total populations (more than 50 millions) of Bangladesh are consuming arsenic (As) through drinking and cooking (Misbahuddin, 2003). Chronic As poisoning can cause serious health problems including cancers, hyperkeratosis, restrictive lung disease, and ischaemic heart disease (Rossman, 2003; Mandal and Suzuki, 2002), noncancerous skin lesions, bronchitis, hepatomegaly, neuropathy, peripheral vascular diseases (e.g. gangrene), cardiovascular disease (Smith et al., 1998). Over production of free radicals leading to oxidative stress has been postulated as one of the major mechanism behind As induced toxicities in different organs (Kokilavani et al., 2005). Improvement of nutritional status (Mitra et al. 2004) and use of chelating agents are recommended (Kalia and Flora, 2005). But the role of chelating agents in chronic As poisoning is not beyond doubt (Guha Mazumder et al., 1998). Vitamin A, E, C regimen with As free water was proved to be effective in improving As induced melanosis and keratosis (Ahmad et al., 1998). Spirulina extract plus zinc was found to be advantageous in patients of chronic As poisoning (Misbahuddin et al., 2006). The potential of dietary antioxidants to reduce the As burden in human by increasing its metabolism has drawn attention in recent years (Dey, 2002; McCall and Balz, 1999). Some investigators suggested that the effectiveness of retinol, $\beta$-carotene (Chung et al., 2006), ascorbic acid (Saha, 2005), selenium (Spallholz et al., 2004), tocopherol (Ramanathan et al., 2003), alphalipoic acid (Tabassum, 2006), spinach (Umar, 2007) for the reduction of body burden of chronic As toxicity. Spinach is a rich source of antioxidants and micronutrients and can increase the serum antioxidant capacity in humans (Cao et al., 1998). In view of the reduction of body burden capacity of spinach in chronic As poisoning by its antioxidant properties the present study was carried out to document the effectiveness of spinach against As induced toxicity in rats.

\section{MATERIALS AND METHODS}

This experiment was carried out during July to October, 2008 in the Arsenic Detection and Mitigation Laboratory (ADM Lab), Department of Pharmacology, Faculty of Veterinary Science, Bangladesh Agricultural University, Mymensingh. 


\section{Z. Islam and others}

\section{Animals}

Thirty six adult female non-pregnant apparently healthy Long Evans (Rattus novegicus) rats (age about 120 days and average BW was $154.5 \mathrm{~g}$ ) were collected from the Department of Pharmacology, Bangabandu Sheikh Mujib Medical University, Dhaka. Rats were acclimatized for 15 days in the laboratory for the experiment. The animals were housed in compartmented rectangular metallic cage under standard laboratory conditions (12 h light: $12 \mathrm{~h}$ dark, $25 \pm 2^{\circ} \mathrm{C}$ and humidity $60 \pm 5 \%$ ).

\section{Experimental trial}

The experimental trial was conducted for 30 days. Before giving treatment rats were randomly grouped into 3 equal groups $(\mathrm{n}=12)$, denoted as $\mathrm{T}_{0}$ (control), $\mathrm{T}_{1}$ (As treated) and $\mathrm{T}_{2}$ (As plus spinach treated) group. Rats of group $\mathrm{T}_{0}$ were maintained with normal feed and water ad libitum, which of group $\mathrm{T}_{1}$ were treated with Sodium arsenite $\left(\mathrm{NaAsO}_{2}\right.$; MERCK, E.Merck, Darmstadt, Germany) @ $5 \mathrm{mg} / \mathrm{kg} \mathrm{BW}$ orally in drinking water daily. The animals of group $\mathrm{T}_{2}$ were treated with $\mathrm{NaAsO}_{2} @ 5 \mathrm{mg} / \mathrm{kg}$ BW plus aqueous extract of spinach @ 100mg $/ \mathrm{kg} \mathrm{BW}$ orally in drinking water daily.

\section{Preparation of treatment materials}

\section{Sodium arsenite solution}

On the basis of the total body weight of the rats, the required amount of $\mathrm{NaAsO}_{2}$ for a day $(5 \mathrm{mg} / \mathrm{kg} \mathrm{BW})$ was weighted separately for each group of rats and mixed with the drinking water daily immediate before allocation for drinking for that particular group. Generally, $10 \mathrm{ml}$ drinking water per rat was allotted for mixing $\mathrm{NaAsO}_{2}$ to make sure that the full amount of $\mathrm{NaAsO}_{2}$ was taken by the rats. After finishing the drinking of the $\mathrm{NaAsO}_{2}$ mixed water, normal drinking water was supplemented ad libitum.

\section{Spinach extract and its solution}

Freshly harvested spinach was collected from the local market. The roots of spinach were removed by sharp knife then the remaining portion were thoroughly washed several times with tape water and finally with deionized distilled water and the water was removed by keeping on drying cabinet for 2 hours at room temperature. These were kept on a rectangular netted plastic basket for 2 hours to remove washing water. Then, the leaves and soft stalks were separated and chopped into small pieces and kept under an electric fan at room temperature in an air conditioned room for 48 hours then these were dried in an electric oven at $55^{\circ} \mathrm{C}$ until the succulent mass was dried fully. The dried spinach was grinded with an electric grinder and then the grinded mass was sieved with $2 \mathrm{~mm}$ wire sieve to get fine powder. Fifteen gram of spinach powder was weighed and thoroughly mixed with $1000 \mathrm{ml}$ deionized distilled water and kept for 24 hours at room temperature. After that the solution was filtered using electric filtration unit and kept in a refrigerator as stock spinach aqueous extract until used.

For each group required amount of the spinach extract $(100 \mathrm{mg} / \mathrm{kg} \mathrm{BW})$ was supplied with drinking water $(10 \mathrm{ml} / \mathrm{rat})$ daily and it was made sure that the full amount of spinach extract was taken by the rats. After finishing the drinking of the spinach extract mixed water, normal drinking water was supplemented ad libitum.

\section{Body weight (BW)}

Individual BW of rats of each group were taken on Day 0 (Day $0=$ immediate previous day of starting treatment), Day 10, Day 20 and finally on Day 30 and the results were recorded.

\section{Sampling}

At every 10 days interval (on Day 10, Day 20 and Day 30) 4 rats from each group were randomly selected for sacrifice following chloroform anesthesia. About $5 \mathrm{ml}$ of blood was collected from each rat by cardiac puncture for serum collection for the determination of biochemical parameters (SGOT, SGPT and serum creatinine). Lungs, liver, and kidneys were collected, which were washed with physiological saline and were taken into the respectively pre-marked zipper polythene bags. Serum was separated from collected blood following centrifugation of blood in the next morning and taken into pre-marked Eppendorf tubes. All the organs and serum were preserved at $-20^{\circ} \mathrm{C}$ until analysis. 


\section{Digestion of samples for detection}

Laboratory chemicals used in the digestion and detection of as were trace analytical grade. The digestion of tissue samples was carried out using the acid mixture of concentrated nitric (69\%; VWR International Limited, pool, BH 15 1TD, England) plus perchloric acid (70\%; Merck, KGaA, Darmstadt, Germany) at the ratio of 9:4 (R). Half a gram of tissue sample was weighed in electric balance and taken individually into each digestion tube. Then $5 \mathrm{ml}$ of acid mixture was added to each digestion tube and left overnight at room temperature for predigestion. In the next morning, the digestion tubes were heated in a block digester at $120^{\circ} \mathrm{C}$ for several hours until clear solution appeared. During the heating period the digestion tubes were gently shaken every after half an hour to make the contents homogeneous and to enhance brown fume (nitrous oxide fume) release. After complete digestion, the tubes were removed from the block digester and was left it until cooling, then volume to $50 \mathrm{ml}$ and filtered individually with filter paper (Whatman 42) and preserved separately in acid washed $50 \mathrm{ml}$ polyprophylene vial and kept at room temperature until As determination. A blank was prepared in same way.

\section{Preparation of As standard solutions}

Arsenic standard solutions were prepared with the As concentration of $0,5.0,10.0,15.0,20.0$ and $25.0 \mu \mathrm{g} / \mathrm{L}$ in $10 \% \mathrm{HCl}$ in separate $25 \mathrm{ml}$ calibrated volumetric flasks from $1000 \mu \mathrm{g} \mathrm{As} / \mathrm{L}$ working solution of arsenic pentaoxide $\left(\mathrm{As}_{2} \mathrm{O}_{5}\right)$.

\section{Determination of arsenic}

Arsenic was detected with Hydride Generation Atomic Absorption Spectrophotometer (HG-AAS; PG-990, PG Instruments Ltd. UK) using AA Win software. Ten percent $\mathrm{HCl}$ was used as carrier liquid and $1.5 \%$ potassium borohydride plus $0.3 \%$ sodium hydroxide solution was used for hydride formation. Reading were taken from the software Excel sheet and calculated on the basis of volume and weight of the sample.

\section{Examination of serum samples}

Serum glutamate oxaloacetate transaminase (SGOT), Serum glutamate pyruvate transaminase (SGPT) and Serum creatinine of the collected serum samples were determined by Reflotron ${ }^{\circledR}$ Plus (Boehringer Mannheim, Germany) according to the method described by Deneke and Rittersdorf (1984) and Deneke et al. (1985).

\section{Statistical analysis}

The experimental data were designed in CRD and analyzed statistically using one way ANOVA with the help of the SPSS 11.5 software. Mean comparisons of the treatment were made by the Duncan's Multiple Range Test (DMRT) (Steel and Torrie, 1980).

\section{RESULTS AND DISCUSSION}

At the beginning of the experiment average body weight of the rats was $154.5 \mathrm{~g}$ and no significant difference was observed among the three groups. After 30 days of treatment the body weight of $T_{0}$ (control) and $T_{1}$ (As treated) group were increased but there were no significant difference between them and $\mathrm{T}_{2}$ (As plus spinach treated) group lost its body weight and differ significantly $(\mathrm{p}<0.01)$ with that of $\mathrm{T}_{0}$ and $\mathrm{T}_{1}$ groups. Highest body weight $\left(199.75 \mathrm{~g}\right.$ ) was found in control group (Table 1). Increased body weight in $\mathrm{T}_{1}$ group rats does not meet with the findings of Jun et al. (2008) who found As significantly $(\mathrm{p}<0.01)$ decreases the body weight of rats. Significant decrease in body weight in spinach treated group may be due to the presence of any substance in spinach which causes reduced efficiency of food conversion or impaired absorption of food from the gastrointestinal tract or may cause any metabolic defect at cellular level. The actual cause behind increased body in As treated group and decreased body weight in spinach treated group is not clear.

Feeding of As in rats increased As concentrations in lung, liver and kidneys; spinach treatment significantly $(\mathrm{p}<0.01)$ lowered As contents in those organs and found effective against As induced toxicity in rats (Table 2). Significantly increased $(p<0.01)$ levels of As in the lung, liver and kidney of $T_{1}$ group rats compared to $T_{0}$ and $T_{2}$ groups following 30 days feeding of sodium arsenite $(5 \mathrm{mg} / \mathrm{kg} \mathrm{BW})$ were observed. The concentration of As in tissues of $T_{1}$ group rats was increasing in trend at different sampling days. From this finding it can be said that tissue retention of As may be increased with the length of exposure period which is agreed with the findings of previous workers (Nasir et al. 2002; Kamaludin and Misbahuddin, 2006). They showed that administering As to rats induces significant increase in As accumulation in tissue with the progress of time. This may be due to rate of excretion of As is less than the rate of exposure or As may has the tendency to accumulate in the tissue. 


\section{Z. Islam and others}

As concentration detected in lung, liver and kidney of As treated group $\left(\mathrm{T}_{1}\right)$ of which highest accumulation was found in kidney followed by lung and liver (Table 2) which support the findings of Kenyon et al. (2008) they found that tissue As accumulation was greatest in kidney followed by lung, urinary bladder, skin, blood and liver. Which may due to monomethyl arsenous acid and dimethyl arsonous acid, the metabolic product of inorganic As in liver after methylation. These are excreted through kidney and the rate of methylation may be more than the rate of excretion. But Umar (2007) and Marafante (1982) found highest accumulation of As in lung followed by liver and kidney. Significantly $(\mathrm{p}<0.01)$ lower level of As was found in lung, liver and kidney of spinach treated group compared to that of As treated group on Day 10, Day 20 and Day 30 (Table 2). This finding supports the result of Umar (2007) who stated that hexan extract of spinach was effective in the removal of As from the As loaded tissues in rats. The values of SGOT were increased significantly $(p<0.01)$ in As treated rats compared to control and spinach treated groups (Table 3). There was no significant difference between the values of SGOT of control and spinach treated group. This finding supports with the findings of Jun et al. (2008) who found elevated serum SGOT levels in mice treated with arsenite and arsenate. This indicates that As causes liver injury. Chronic exposure of experimental animals to inorganic As has been shown to produce various liver lesions, including inflammation and oxidative damage, fatty accumulation, parenchymal cell degeneration, hepatic fibrosis and liver proliferative lesions (Mazumder, 2005). From this findings it may be stated that spinach some how prevent liver injury caused by As.

Table 1. Effect of arsenic and spinach on the body weight of rats

\begin{tabular}{|l|l|l|l|l|l|l|}
\hline $\mathrm{S} / \mathrm{N}$ & Groups of rats & Treated with & \multicolumn{4}{l|}{ Body weight $(\mathrm{g})$} \\
\cline { 3 - 7 } & & & $\begin{array}{l}\text { Day 0 } \\
(\mathrm{n}=36)\end{array}$ & $\begin{array}{l}\text { Day 10 } \\
(\mathrm{n}=36)\end{array}$ & $\begin{array}{l}\text { Day 20 } \\
(\mathrm{n}=24)\end{array}$ & $\begin{array}{l}\text { Day 30 } \\
(\mathrm{n}=12)\end{array}$ \\
\hline 1 & $\mathrm{~T}_{0}$ & Control & $155.40 \pm 5.56$ & $174.70 \pm 5.90^{\mathrm{a}}$ & $185.57 \pm 7.53^{\mathrm{a}}$ & $199.75 \pm 11.95^{\mathrm{a}}$ \\
\hline 2 & $\mathrm{~T}_{1}$ & Sodium arsenite & $154.90 \pm 4.14$ & $165.80 \pm 4.06^{\mathrm{a}}$ & $174.57 \pm 4.81^{\mathrm{a}}$ & $176.50 \pm 6.09^{\mathrm{a}}$ \\
\hline 3 & $\mathrm{~T}_{2}$ & $\begin{array}{l}\text { Sodium arsenite }+ \\
\text { Spinach }\end{array}$ & $153.20 \pm 4.88$ & $148.90 \pm 4.82^{\mathrm{b}}$ & $151.14 \pm 8.84^{\mathrm{b}}$ & $140.25 \pm 12.24^{\mathrm{b}}$ \\
\hline 4 & \multicolumn{2}{|l|}{ Level of significance } & $\mathrm{NS}$ & $* *$ & $* *$ & $* *$ \\
\hline
\end{tabular}

Figures indicate the mean $\pm \mathrm{SE}$; NS $=$ Nonsignificant, $* *$ Significant $(\mathrm{p}<0.01)$; Figures with similar superscripts within a column mean did not differ significantly among respective figures, figures with dissimilar superscripts mean differed significantly as per DMRT.

Table 2. Arsenic content of lung, liver and kidney of rats

\begin{tabular}{|c|c|c|c|c|c|c|c|c|c|c|c|}
\hline \multirow[t]{2}{*}{$\mathrm{S} / \mathrm{N}$} & \multirow{2}{*}{$\begin{array}{l}\text { Groups } \\
\text { of rats }\end{array}$} & \multirow[t]{2}{*}{ Treated with } & \multicolumn{3}{|c|}{ Lung (ppb) } & \multicolumn{3}{|c|}{ Liver (ppb) } & \multicolumn{3}{|c|}{ Kidney (ppb) } \\
\hline & & & $\begin{array}{l}\text { Day } 10 \\
n=4\end{array}$ & $\begin{array}{l}\text { Day } 20 \\
n=4\end{array}$ & $\begin{array}{l}\text { Day } 30 \\
n=4\end{array}$ & $\begin{array}{l}\text { Day } 10 \\
n=4\end{array}$ & $\begin{array}{l}\text { Day } 20 \\
n=4\end{array}$ & $\begin{array}{l}\text { Day } 30 \\
n=4\end{array}$ & $\begin{array}{l}\text { Day } 10 \\
n=4\end{array}$ & $\begin{array}{l}\text { Day } 20 \\
\mathrm{n}=4\end{array}$ & $\begin{array}{l}\text { Day } 30 \\
n=4\end{array}$ \\
\hline 1 & $\mathrm{~T}_{0}$ & Control & $\begin{array}{l}0.28 \pm \\
.02^{\mathrm{c}}\end{array}$ & $\begin{array}{l}0.33 \pm \\
0.09^{\mathrm{c}}\end{array}$ & $\begin{array}{l}0.31 \pm \\
0.06^{\mathrm{c}}\end{array}$ & $\begin{array}{l}0.12 \pm \\
0.01^{\mathrm{b}}\end{array}$ & $\begin{array}{l}0.40 \pm \\
0.25^{\mathrm{c}} \\
\end{array}$ & $\begin{array}{l}0.05 \pm \\
0.01^{\mathrm{c}}\end{array}$ & $\begin{array}{l}0.25 \pm \\
.018^{\mathrm{c}}\end{array}$ & $\begin{array}{l}1.71 \pm \\
1.08^{\mathrm{c}}\end{array}$ & $\begin{array}{l}0.11 \pm \\
0.08^{c}\end{array}$ \\
\hline 2 & $\mathrm{~T}_{1}$ & Sodium arsenite & $\begin{array}{l}18.25 \pm \\
1.50^{\mathrm{a}} \\
\end{array}$ & $\begin{array}{l}18.28 \pm \\
0.64^{\mathrm{a}}\end{array}$ & $\begin{array}{l}29.05 \pm \\
1.16^{\mathrm{a}}\end{array}$ & $\begin{array}{l}10.69 \pm \\
0.47^{\mathrm{a}}\end{array}$ & $\begin{array}{l}17.26 \pm \\
2.06^{\mathrm{a}}\end{array}$ & $\begin{array}{l}19.35 \pm \\
1.51^{\mathrm{a}}\end{array}$ & $\begin{array}{l}23.61 \pm \\
3.89^{\mathrm{a}}\end{array}$ & $\begin{array}{l}37.97 \pm \\
2.11^{\mathrm{a}}\end{array}$ & $\begin{array}{l}44.70 \pm \\
3.65^{\mathrm{a}}\end{array}$ \\
\hline 3 & $\mathrm{~T}_{2}$ & $\begin{array}{l}\text { Sodium arsenite } \\
+ \text { Spinach }\end{array}$ & $\begin{array}{l}14.28 \pm \\
0.81^{\mathrm{b}}\end{array}$ & $\begin{array}{l}14.46 \pm \\
1.03^{\mathrm{b}}\end{array}$ & $\begin{array}{l}14.06 \pm \\
1.83^{\mathrm{b}}\end{array}$ & $\begin{array}{l}9.29^{ \pm} \\
1.09^{\mathrm{a}}\end{array}$ & $\begin{array}{l}9.45 \pm \\
1.98^{\mathrm{b}}\end{array}$ & $\begin{array}{l}11.57 \pm \\
3.22^{\mathrm{b}}\end{array}$ & $\begin{array}{l}12.68 \pm \\
0.94^{\mathrm{b}}\end{array}$ & $\begin{array}{l}11.91 \pm \\
0.77^{\mathrm{b}}\end{array}$ & $\begin{array}{l}11.42 \pm \\
2.58^{\mathrm{b}}\end{array}$ \\
\hline 4 & \multicolumn{2}{|c|}{ Level of significance } & $* *$ & $* *$ & $* *$ & $* *$ & $* *$ & $* *$ & $* *$ & $* *$ & $* *$ \\
\hline
\end{tabular}

Figures indicate the mean \pm SE; **Significant $(\mathrm{p}<0.01$ ); Figures with similar superscripts within a column mean did not differ significantly among respective figures, figures with dissimilar superscripts mean differed significantly as per DMRT. 
SGPT values were decreasing with the progress of time in all groups. At day 10, SGPT values of As and As plus spinach treated groups differ significantly $(\mathrm{p}<0.05)$ with that of control but no significant difference was found on day 20 and 30 (Table 3). The results of this study partially agreed with the findings of Richa and Swaran (2005), who found a significant decrease in SGPT activities and suggested hepatic injury following As exposure. Though the liver plays an important role in metabolic processes and detoxification of many xenobiotics, acute exposures to metal like As may lead this metal to accumulate in the liver and cause pathological alterationsMoreover, cell injury of certain organs like liver leads to the release of tissue specific enzymes into the bloodstream which alters the SGOT and SGPT values. Spinach treatment has shown improvement of liver function. However, long-term detail physiological work on liver function for As and As plus spinach could give more precise information.

Table 3. Effect of arsenic and spinach on biochemical parameters of rats

\begin{tabular}{|c|c|c|c|c|c|c|c|c|c|c|}
\hline \multirow{2}{*}{$\begin{array}{l}\text { Groups } \\
\text { of rats }\end{array}$} & \multirow[t]{2}{*}{ Treated with } & \multicolumn{3}{|c|}{ SGOT (U/L) } & \multicolumn{3}{|c|}{ SGPT (U/L) } & \multicolumn{3}{|c|}{ Serum creatinine $(\mathrm{U} / \mathrm{L})$} \\
\hline & & $\begin{array}{l}\text { Day } 10 \\
n=4\end{array}$ & $\begin{array}{l}\text { Day } 20 \\
n=4\end{array}$ & $\begin{array}{l}\text { Day 30 } \\
n=4\end{array}$ & $\begin{array}{l}\text { Day } 10 \\
n=4\end{array}$ & $\begin{array}{l}\text { Day } 20 \\
n=4\end{array}$ & $\begin{array}{l}\text { Day 30 } \\
\mathrm{n}=4\end{array}$ & $\begin{array}{l}\text { Day } 10 \\
n=4\end{array}$ & $\begin{array}{l}\text { Day } 20 \\
n=4\end{array}$ & $\begin{array}{l}\text { Day } 30 \\
n=4\end{array}$ \\
\hline $\mathrm{T}_{0}$ & Control & $\begin{array}{l}50.25 \pm \\
4.13^{\mathrm{b}}\end{array}$ & $\begin{array}{l}54.25 \pm \\
13.30^{\mathrm{b}}\end{array}$ & \begin{tabular}{|l|}
$58.00 \pm$ \\
$13.60^{\mathrm{b}}$
\end{tabular} & $\begin{array}{l}30.0 \pm \\
1.29^{\mathrm{b}}\end{array}$ & $\begin{array}{l}28.8 \pm \\
0.85\end{array}$ & \begin{tabular}{|l|}
$27.0 \pm$ \\
0.58
\end{tabular} & $\begin{array}{l}0.89 \pm \\
0.04 \\
\end{array}$ & $\begin{array}{l}0.93 \pm \\
0.02\end{array}$ & $\begin{array}{l}0.94 \pm \\
0.02 \\
\end{array}$ \\
\hline $\mathrm{T}_{1}$ & Sodium arsenite & $\begin{array}{l}125.0 \pm \\
6.82^{\mathrm{a}} \\
\end{array}$ & $\begin{array}{l}129.3 \pm \\
7.78^{\mathrm{a}}\end{array}$ & $\begin{array}{l}134.3 \pm \\
1.93^{\mathrm{a}}\end{array}$ & $\begin{array}{l}38.0 \pm \\
0.70^{\mathrm{a}} \\
\end{array}$ & $\begin{array}{l}32 . \pm \\
1.96\end{array}$ & \begin{tabular}{|l|}
$26.0 \pm$ \\
0.41 \\
\end{tabular} & \begin{tabular}{|l|}
$0.82 \pm$ \\
0.03 \\
\end{tabular} & $\begin{array}{l}0.88 \pm \\
0.03 \\
\end{array}$ & $\begin{array}{l}0.90 \pm \\
0.03 \\
\end{array}$ \\
\hline $\mathrm{T}_{2}$ & $\begin{array}{l}\text { Sodium arsenite } \\
+ \text { Spinach }\end{array}$ & $\begin{array}{l}60.00 \pm \\
3.37^{\mathrm{b}}\end{array}$ & $\begin{array}{l}65.00 \pm \\
2.38^{\mathrm{b}}\end{array}$ & $\begin{array}{l}75.75 \pm \\
7.40^{\mathrm{b}}\end{array}$ & $\begin{array}{l}35.0 \pm \\
2.48^{\mathrm{a}}\end{array}$ & $\begin{array}{l}32.0 \pm \\
1.78\end{array}$ & $\begin{array}{l}27.0 \pm \\
0.41\end{array}$ & $\begin{array}{l}0.82 \pm \\
0.02\end{array}$ & $\begin{array}{l}0.84 \pm \\
0.05\end{array}$ & $\begin{array}{l}0.89 \pm \\
0.04\end{array}$ \\
\hline \multicolumn{2}{|c|}{ Level of significance } & $* *$ & $* *$ & $* *$ & * & NS & NS & NS & NS & NS \\
\hline
\end{tabular}

Figures indicate the mean \pm SE; NS $=$ Nonsignificant, *significant $(\mathrm{p}<0.05) ; * *$ Significant $(\mathrm{p}<0.01)$; Figures with similar superscripts within a column mean did not differ significantly among respective figures, figures with dissimilar superscripts mean differed significantly as per DMRT.

There was no significant difference observed in the serum creatinine level of all groups of rats throughout the study period (Table 3). The results of this study was similar with the findings of Roger et al. (2000), they showed no consistent changes in blood creatinine levels in rats, mice, guinea pigs and hamsters. Blood creatinine is a common tests used to evaluate kidney function. Kidney dysfunction results in decreased creatinine clearance and therefore increases their blood levels.

From previous works it is well documented that micronutrients and antioxidants has significant role in the treatment of chronic As poisoning (Tabassum, 2006; Saha, 2005; Spallholz et al., 2004). As spinach is a rich source of vitamins, minerals and micronutrients. All of which possess antioxidant properties. Thus, it can be suggested that a combination of vitamins, minerals, antioxidants and other micronutrients could be a novel therapeutic measure for the treatment of arsenicosis. However, exact mechanism of lowering As by treating animals with spinach is yet to known. Further study need to be carried out with spinach extract to ascertain its therapeutic benefits as well as harmful effects in As poisoning.

\section{REFERENCES}

1. Ahmad SA, Faruquee MH, Sayed MHSU, Khan MH, Jalil MA, Ahmed R and Hadi SA (1998). Chronic arsenicosis: Management by vitamin A, E, C regimen. Journal of Preventive and Social Medicine 17: 19-26.

2. Cao G, Russel RM, Lischner N and Prior RL (1998). Serum antioxidant capacity is increased by consumption of strawberries, spinach, red wine or Vitamin C in elderly women. Journal of Nutrition 128: 2383-2390.

3. Chung JS, Haque R, Guha Mazumder DN, Moore LE, Ghosh N, Samanta S and Mitra S (2006). Blood concentration of methionine, selenium, beta-carotene, and other micronutrients in a case-control study of arsenic-induced skin lesions in West Bengal, India. Environmental Research 101: 230-37.

4. Deneke U and Rittersdorf W (1984). Evaluation of the Refloquant GPT (ALT) reagent carriers with Reflotron. Clinical Chemistry 30: 1009.

5. Deneke U, Rittersdorf W and Werner W 1985. Performance data of Reflotron-GOT (AST) dry chemistry test for Reflotron. Clinical Chemistry. 31: 921. 


\section{Z. Islam and others}

6. Dey R (2002). Management protocol for arsenicosis cases. Report of a Regional Consultation of World Health Organization on Arsenicosis. Case-Detection, Management and Surveillance, India, 5-9 November 2002.

7. Guha Mazumder DN, Ghoshal UC, Saha J, Santra A, De BK, Chatterjee A, Dutta S, Angle CR and Centeno JA (1998). Randomized placebo-controlled trial of 2,3- dimercaptosuccinic acid in therapy of chronic arsenicosis due to drinking arsenic-contaminated subsoil water. Journal of Toxicology- Clinical Toxicology 36: 683-90.

8. Jun WU, Jie LIU, Michael P. Waalkes, Ming-Liang Cheng, Ling LI, Cheng-Xiu LI, and Qing Yang (2008) High Dietary Fat Exacerbates Arsenic Induced Liver Fibrosis in Mice Experimental Biology and Medicine 233:377-384.

9. Kalia K and Flora SJ (2005). Strategies for safe and effective therapeutic measures for chronic arsenic and lead poisoning. Journal of Occupational Health 47: 1-21.

10. Kamaluddin $M$ and Misbahuddin M (2006). Zinc supplement reduces tissue arsenic concentration in rats. Bangladesh Medical Research Council Bulletin 32:87-91

11. Kenyon EM, Hughes MF, Adair BM, Highfill JH, Crecelius EA, Clewell HJ and Yager JW (2008) Tissue distribution and urinary excretion of inorganic arsenic and its methylated metabolites in C57BL6 mice following subchronic exposure to arsenate in drinking water. Toxicology and Applied Pharmacology 232:448-455

12. Kokilavani V, Devi MA, Sivarajan K and Panneerselvam C (2005). Combined efficacies of DL-á-lipoic acid and meso 2,3 dimercaptosuccinic acid against arsenic induced toxicity in antioxidant systems of rats. Toxicology Letters 160: 1-7.

13. Mandal BK and Suzuki KT (2002). Arsenic round the world: a review. Talanta 58: 201-235.

14. Marafante E, Bertolero F, Edel J, Pietra R and Sabbioni E (1982). Intracellular interaction and biotransformation of arsenite in rats and rabbits. Science of the Total. Environment 24:27-39.

15. Mazumder DN (2005). Effect of chronic intake of arsenic-contaminated water on liver. Toxicology and Applied Pharmacology 206: 169-75.

16. McCall MR and Balz F (1999). Can antioxidant vitamins materially reduce oxidative damage in humans? Free Radical Biology and Medicine 26: 1034-1053.

17. Misbahuddin M (2003). Consumption of arsenic through cooked rice. Lancet 361: 435-36.

18. Misbauddin M, Islam AZ, Khandker S, Ifthaker- Al- Mahmud, Islam N and Anjumanara (2006). Efficacy of spirulina extract plus zinc in patient of chronic arsenic poisoning: a randomized placebo- controlled study. Clinical Toxicology (Philadelphia) 44: 135-141.

19. Mitra SR, Mazumder DNG, Basu A, Block G, Haque R, Samanta S, Ghosh N, Smith MMI, Ehrenstein OSV and Smith AH (2004). Nutritional factors and susceptibility to arsenic-caused skin lesions in West Bengal, India. Environmental Health Perspectives 112: 1104-1109.

20. Nasir M, Misbahuddin M and Ali SMK 2002. Selenium intervention in reducing arsenic levels in different tissues. Proceedings of the 2nd International Conference on Bangladesh Environment, 2002. Ahmed, M.F.; Tanveer, S.A.; Badruzzaman, A.B.M. (eds). ICBEN-2002, Dhaka, Bangladesh 2002: 343-52.

21. Rahman W (2006). Arsenic exposure in Bangladesh: The reproductive and development health effects in humans. Philadelphia Annual Meeting, USA. Paper No. 67-3.

22. Ramanathan K, Shila S, Kumaran S and Panneerselvam C (2003). Protective role of ascorbic acid and $\alpha$-tocopherol on arsenic-induced microsomal dysfunctions. Human and Experimental Toxicology 22: 129-36.

23. Richa G and Swaran JS Flora (2005). Protective Value of Aloe vera against Some Toxic Effects of Arsenic in Rats. Phytotherapy Research 19: 23-28.

24. Roger D, Mitchell, Felix Ayala-Fierro and Dean E Carter (2000). Systemic indicators of inorganic arsenic toxicity in four animal species. Journal of Toxicology and Environmental Health (Part A) 59:119-134.

25. Rossman TG (2003). Mechanism of arsenic carcinogenesis: an integrated approach. Mutation Research 533: 37-65.

26. Saha B (2005). Effect of ascorbic acid on reduced glutathione level in arsenic-loaded isolated liver tissues of rat. Bangladesh Journal of Pharmacology 1: 68-71.

27. Smith AH, Goycolea M, Haque R and Biggs ML (1998). Marked increase in bladder and lung cancer mortality in a region of northern Chile due to arsenic in drinking water. American Journal of Epidemiology 147: 660-669.

28. Spallholz JE, Mallory BL and Rhaman MM (2004). Environmental hypothesis: is poor dietary selenium intake an underlying factor for arsenicosis and cancer in Bangladesh and West Bengal, India. Science of the Total Environment 323 : 21-32.

29. Steel RGD and Torrie JH (1980). Principles and Procedures in Statistics. M.C Graw-Hill Book Company Inc. New York, USA.

30. Tabassum NE (2006). Effect of á-lipoic acid on the removal of arsenic from arsenic-loaded isolated liver tissues of rat. Bangladesh Journal of Pharmacology 1: 27-32.

31. Umar BU (2007). Effect of hexan extract of spinach in the removal of arsenic from rat. Bangladesh Journal of Pharmacology 2: 27-34. 